\title{
CHILDREN'S RIGHTS AND CHILDHOOD STUDIES AS A CHALLENGE AND A DRIVER OF SOCIAL CHANGE
}

\author{
URSZULA MARKOWSKA-MANISTA ${ }^{1} \&$ ANNA ODROWĄŻ-COATES ${ }^{2}$ \\ ${ }^{1}$ University of Warsaw, Faculty of Education, Mokotowska 16/20, 00-651 Warsaw, Poland. ORCID: \\ 0000-0003-0667-4164, Email: u.markowska-ma@uw.edu.pl \\ ${ }^{2}$ Maria Grzegorzewska University, UNESCO Janusz Korczak Chair in Social Pedagogy, Szczesliwicka 40, \\ 02-353 Warsaw, Poland. ORCID: 0000-0002-2112-8711,Email: acoates@aps.edu.pl
}

\begin{abstract}
This paper contains an introduction to a selection of papers across social sciences and humanities, based on empirical explorations and theoretical conceptualizations. Authors highlight the issues of parental roles, parental styles, child and family positioning in the family and society. The lens of children's rights and participatory approaches is also discussed. Authors focus on diverse practices in parenting, different approaches to children's agency and freedom of choice, family as a negotiated space mediated by culture, children's position in family and society, life chances and wellbeing, critical approaches to children's rights perspectives, early intervention, socio-political context, finally Freire's and Korczak's pedagogies.

KEYWORDS: social pedagogy, education, socialization, participatory research, childhood
\end{abstract}

$\mathrm{T}$ his collection of papers dedicated to children's rights, childhood studies and the use of children's rights pedagogical lenses, creates a special space to explore both nature and culture, and their interplay with the ideals of childcare, children's wellbeing and children's upbringing. At the same time, it draws attention to new topics and approaches to research in contemporary interdisciplinary social studies, in which a key 
role is played by childhood and children's rights together with early childhood studies. We started working on the collection of papers prior to the COVID-19 pandemic and whilst the situation remains serious in many parts of the world, the contributors and reviewers have made tremendous efforts to prepare the issue in good time. We are very grateful to them and inspired by their commitment to the cause.

Early childhood is of paramount importance for a child's development and later success in life, yet parents often do not have the knowledge and support to be the best parents for their children at this critical stage. Tired, exhausted and confused, anxious about their changing roles and changing obligations, parents may miss out on the positive aspects of parenthood and at the same time unknowingly affect their children in a negative way. Every developmental stage brings new challenges and questions for parents that often remain unanswered or inadequately addressed by pseudo-experts and heresy. This is an area for social pedagogues, social workers, psychologists, medical professionals and social politicians to explore and clarify. The effects of natural and cultural pressures give us an interesting opportunity to reflect on the roots of traditions and praxis of childcare, and parental practices observed in different cultures in different parts of the world and in different epochs (c.f. Bernheim 1989). There are so many areas that researchers can explore, starting with Korczak's innocent novel Bobo from 1914 (Odrowaz-Coates \& Vucic 2019), followed by Buber's (1984) concepts of dialogical thinking, Freeman's (1992) ideological underpinning of child socialization, Gest et al. (1999) and on early intervention and the changing patterns of fatherhood worldwide (Hofner et al. 2011). These issues pertain to formal and informal socialization and also to educational systems. Baranowski (2020) brings attention to changes in education post the neoliberal turn through the introduction of the 'worthless education' idea to highlight the consequences of the ongoing educational transformations that underpin all levels of societies and have an impact on children's upbringing.

In a world built on distinctions: us and the other, a child and an adult, rights and duties, this volume is also a path to togetherness and overcoming the discourses of 'othering' (Odrowaz-Coates 2015, 2018) and an opportunity to look at written and unwritten children's rights (Markowska-Manista 2017). We oppose the practices of coercion in children's upbringing and advocate for participatory models of working and being with children and young people (Percy-Smith \& Thomas 2009). The papers explore not only the issues highlighted above, but also the research praxis in the field of childhood studies. Markowska-Manista (2018) asks: "whose participation?” when considering participatory research with children and youths. This approach seems particularly necessary today, in fact it is indispensable in researching children and matters that concern them, as well as their activism (Torres-Harding et al. 2018; Budde, Markowska-Manista 2020) and was postulated by Judith Ennew in her research and activities with children. As Ennew stressed, children, like adults, have the right to be properly researched (Ennew, Plateau 2005). Participatory research and praxis enable a broader insight into children's situations and their activism, while impelling us to reflect on changes in approaches to research conducted with children, on childhood and children's rights (Markowska-Manista 2020: 9). Much has changed in the recent 
decade, both in theory and practice of children's and youth's participation, both in a local and global dimension. Today, 'adultist' or 'tokenist' approaches to research and praxis concerning children, the largest minority of the world, seem misplaced. The world in an era of pandemic, forces us to look at children's right to participation (Collins et al. 2021). It obligates us to consider participation within important transformative praxis, praxis that decolonises stereotypical approaches and opens adults' eyes to new challenges.

In this collection of papers, the authors explore a range of topics. The paper by Dr Offiong and Uduigwomen, dedicated to socio-cultural values in Calabar, contains analysis of the history and value system that was associated with child upbringing in Nigeria. Communalism, as the authors demonstrate, ensured child socialization from birth, and was considered a common practise in the African context until European colonialization and the eventual introduction of capitalism, which, in the authors' view, contributed to the negative impact on overall children's rights in Nigeria. Magdalena Roszak writes about the phenomenon of parental alienation based on the netnographic study of parental conflict, whilst Megan MacCormac and Katherine MacCormac explore the issues of language policy for children with a migrant background in Canada. The MacCormac article is based on an in-depth empirical study and is embedded in a children's rights perspective. The contribution of the Sudanese researcher, Dr Nagmeldin Kraramalla-Gaiballa focuses on solutions to violence against children in the context of FGM, underage marriage, trafficking and laws that violate the dignity of Sudanese children, allowing for punishments such as flogging, imprisonment and death. Dr Turczyk writes about the child's right to a family and the participatory character of human development using an overview of local and international policy documents. A contributor from Turkey, Dr Seran Demiral, focusses on children's rights to protection, provision and participation. The author introduces a fourth area to add to the discussion, the area of children's power and merges it in Korczak's children's journal context. Furthermore, the empirical study of narratives from sex workers follows. Their experiences are linked to the socialization processes in childhood. Dr Gardian-Małkowska reveals issues of male prostitution and the motivation of clients, viewed through the sex workers' eyes. Moreover, the issue contains two contributions from early-stage researchers. In the first one, Sandra Kwaśniewska-Paszta focuses on evoking empathy in children from an early age. This is followed by Joanna Pawłowska, who writes about gender stereotypes in popular fairy tales. The issue closes with the book review by Professor Mark Bernheim. The reviewed book is dedicated to the unknown history of Jewish-Finnish paradoxes of identity conflict and survival during the World War II and was recently translated into English and published in the US.

FUNDING: This research received no external funding.

CONFLICT OF INTEREST: The authors declare no conflict of interest. 


\section{REFERENCES}

Baranowski, Mariusz. 2020. "A contribution to the critique of worthless education: between critical pedagogy and welfare sociology." Globalisation, Societies and Education 18/4: 391-405. https://doi.org/10.1080/14767724.2020.1732195

Bernheim, Mark. 1989. Father of the Orphans: The Story of Janusz Korczak. New York: Lodestar Books.

Buber, Martin. 1984. I and Thou. New York: Scribner.

Budde, Rebecca \& Urszula Markowska-Manista, eds. 2020. Childhood and Children's Rights between Research and Activism: Honouring the Work of Manfred Liebel. Wiesbaden: Springer VS.

Collins, Tara M., Irene Rizzini, \& Amanda Mayhew. 2021. "Fostering global dialogue: Conceptualisations of children's rights to participation and protection.” Children \& Society 35(2): 295-310.

Ennew, Judith \& Dominique Pierre Plateau. 2005. “I cry when I am hit': Children have the right to be properly researched." Paper contributed to UNESCO, Eliminating Corporal Punishment - The Way Forward to Constructive Child Discipline. Paris: UNESCO.

Freeman, Michael. 1992. The Ideologies of Children's Rights. Dordrecht (NL): Martinus Nijhoff Publishers.

Gest, Scott D., Joseph L. Mahoney, \& Robert B. Cairns. 1999. “A Developmental Approach to Prevention Research: Configural Antecedents of Early Parenthood." American Journal of Community Psychology 27. doi:10.1023/A:1022185312277

Höfner, Claudia, Cornelia Schadler, \& Rudolf Richter. 2011. "When Men Become Fathers: Men's Identity at the Transition to Parenthood.” Journal of Comparative Family Studies 42(5): 669-686.

Korczak, Janusz. 1914. Bobo. Warsaw: G. Centenerszwer i S-ka.

Markowska-Manista, Urszula. 2018. “The ethical dilemmas of research with children from the countries of the Global South. Whose participation?" Polish Journal of Educational Studies 71(1): 51-65.

Markowska-Manista, Urszula. 2020. “O potrzebie dekolonizacji współczesnych badań nad dzieciństwem i prawami dziecka w krajach Globalnego Południa i Globalnej Północy. Rozważania wstępne.” Przegląd Krytyczny 2(1): 9-20. https://doi. org/10.14746/pk.2020.2.1.01

Markowska-Manista, Urszula. 2017. “The Written and Unwritten Rights of Indigenous Children in Central Africa - Between the Freedom of 'Tradition' and Enslavement for 'Development.'” Pp. 127-142 in Symbolic Violence in Socio-Educational Contexts: A Post-Colonial Critique, edited by A. Odrowąż-Coates \& S. Goswami. Warszawa: Wydawnictwo Akademii Pedagogiki Specjalnej.

Odrowaz-Coates, Anna. 2015. "Is gender neutrality a post-human phenomenon? The concept of 'gender-neutral' in Swedish education." Journal of Gender and Power 3(1): 113-133.

Odrowaz-Coates, Anna \& Basia Vucic. 2017. “The Infant, Early Childhood Development and Child Rights: Re-awakening Opportunities for Social Pedagogy.” Ped- 
agogika Społeczna 2(64): 35-58.

Odrowaz-Coates, Anna. 2018. “Migrant children-'added value' in globalized societies and advanced economies of the 21st century: A social justice manifesto for UNESCO Summer School 2017.” Pp. 17-32 in Refugee and migrant children's adaptation - theory, research, praxis, edited by U. Markowska-Manista. Warsaw: Wydawnictwo Akademii Pedagogiki Specjalnej.

Percy-Smith, Barry \& Thomas Nigel, eds. 2009. A handbook of children and young people's participation: Perspectives from theory and practice. London: Routledge.

Scaramella, Laura V. \& Leslie D. Leve. 2004. "Clarifying parent-child reciprocities during early childhood: the early childhood coercion model." Clincial Children and Family Psychological Review 7(2): 89-107. https://doi.org/10.1023/B:CCFP.0000030287.13160.a3

Torres-Harding, Susan, Baber Ashley, Julie Hilvers, Hobbs Nakisha, \& Michael Maly. 2018. "Children as agents of social and community change: Enhancing youth empowerment through participation in a school-based social activism project. Education." Citizenship and Social Justice 13(1): 3-18. doi:10.1177/174619791668464

\section{BIOGRAPHICAL NOTE}

Urszula Markowska-Manista, $\mathrm{PhD}$ - is field researcher in education in culturally diversified environments and indigenous childhood and youth studies concerning children's rights. Since 2016, she has been the director of and lecturer in the MA Childhood Studies and Children's Rights (MACR, Berlin, Potsdam) and is assistant professor at the University of Warsaw (Faculty of Education).

Anna Odrowąż-Coates, $\mathrm{PhD}$ is the chairholder at the UNESCO/Janusz Korczak Chair in Social Pedagogy, and an associate professor in social pedagogy at the Maria Grzegorzewska University in Warsaw, Poland.

OPEN ACCESS: This article is distributed under the terms of the Creative Commons Attribution Non-commercial License (CC BY-NC 4.0) which permits any non-commercial use, and reproduction in any medium, provided the original author(s) and source are credited.

ARTICLE HISTORY: Received 2021-02-19 / Accepted 2021-02-25 
